\title{
A case study on economic cost increment in urban highway work zones
}

\author{
Sasika Ranawaka and Handunneththi R. Pasindu
}

\begin{abstract}
Highway work zones are present in most urban and rural road networks due to road rehabilitation, maintenance, utility installation works that are carried out on roadways. The impacts related to highway work-zone include traffic delays, vehicle operating cost increase, increase in road accidents, accessibility restrictions, deterioration of air quality, noise and vibration issues. This is a major concern for the public and road users. Therefore, it is important to evaluate the impact on highway work-zones especially in urban areas where impacts are generally higher. The study focuses on evaluating the economic cost of highway work-zone on an urban road network considering its impact on travel time and vehicle operating cost. The economic cost calculations were conducted using HDM-4 software. Evaluation of the economic impact of work zones will lead improved workzone management practices which will ultimately benefit the road users and general public.
\end{abstract}

Index Terms - Highway cost, work zone, accident-related, HDM-4

\section{INTRODUCTION}

$\mathrm{T}$ HIS Highway work zones are an integral part of a road network where road rehabilitation, maintenance, upgrading, utility installation work is being carried out on regular basis.

Highway work-zone is an area of a traffic way with highway construction, maintenance, or utility-work activities. A work zone is typically marked by signs, channeling devices, barriers, pavement markings, and/or work vehicles. It extends from the first warning sign or flashing lights on a vehicle to the "End of Road Work" sign or the last traffic control device.

During the time of rehabilitation, there are many inconveniences caused to the general public. It includes road users and nearby residents, shops, hospitals, courts, etc. Specifically, the following have been identified by Griffith and Lynde [1] as the major inconveniences caused by a highway rehabilitation work zone.

- $\quad$ Effect of work zone on daily schedule of school bus drivers, bus drivers etc.

- $\quad$ Access issues for business owners in the work zone
- Utility interruptions for residents and business owners

- Inadequate law enforcement inside work zones

- $\quad$ Effect of low ground clearance vehicles like cars on the flow speed

- $\quad$ Effect on emergency vehicles

Further, Mettananda and Pasindu [2] have identified sound and air pollution, lack of planning, drainage disturbances, and not following of guidelines in addition to the above issues.

Although a set of guidelines which mostly comply with guidelines of developed countries exist in Sri Lanka, the enforcement has become the issue. Contractors are not regularly checked to be following the guidelines nor are they imposed fines or penalties upon infringement. This approach has led to poor roadway conditions during road rehabilitations, which has resulted in lossof money to the economy. Therefore, it is necessary to carry out extensive checks on guideline application, and also to develop and implement improved set of guidelines for highway work zones.

One of the main issues with a highway work zone is the impact of it to the economy of the country, which is knows as work zone road user cost. The economic impact occurs in few main aspects.

- Vehicle operating cost

- Travel delay cost

- Emission cost

- Damage to the environment

- Safety cost

Out of these, Vehicle operating cost (VOC) and travel delay cost are evaluated for a major arterial highway in Sri Lanka in this study.

HDM-4 by world bank is used for economic analysis in the study.

\section{OBJECTIVES}

The main objective of this study is to evaluate the economic impact of a work zone in a busy urban highway. The relationship between roughness and travel speeds, and vehicle operating cost is to be established. 


\section{Evaluation of Road User Cost On Highway Work ZONES}

\section{A. Effect of Roughness on Vehicle Operations}

\section{1) Introduction to Pavement Roughness}

Pavement condition is represented by international roughness index (IRI), a globally recognized parameter to represent the condition of a road pavement. A higher IRR value would represent a road in poor condition with surface irregularities, unevenness and distresses. Typically, roads with IRR values of 6 above are considered to be in poor condition and IRR exceeding 10 are considered to be unsuitable for frequent movement of traffic.

\section{2) Fuel consumption}

Chatti and Zaabar [3] developed speed and fuel consumption equation with the inclusion of roughness to demonstrate the effect of roughness on fuel consumption. Back in 1985, Patterson and Watantada [4] found out that a truck doing $80 \mathrm{~km} / \mathrm{h}$ in a gravel road uses $18 \%$ more fuel compared to a paved road. That was a direct indication of affect of roughness for fuel consumption. The fuel consumption model used in HDM-4 is gives below [3].

$$
I F C=f\left(P_{t r} P_{a c c s}+P_{\text {eng }}\right)=\frac{1000}{v} *(\max (\alpha, \xi * \text { Ptot } *(1+d F u e l)))
$$

Where:

IFC $=$ Instantaneous fuel consumption $(\mathrm{mL} / \mathrm{km})$

$V=$ Vehicle Speed $(\mathrm{m} / \mathrm{s})$

$P_{t r}=$ Power required to overcome traction forces $(\mathrm{kW})$

$P_{a c c s}=$ Power required for engine accessories (eg:fan,belt,alternator etc) (kW)

$P_{\text {eng }} \quad=$ Power required to overcome internal engine friction

$\boldsymbol{\alpha}=$ Fuel consumption at idling $(\mathrm{mL} / \mathrm{s})$

$\xi=$ Fuel to power efficiency factor $(\mathrm{mL} / \mathrm{kw} / \mathrm{s})$

$$
\xi=\xi_{b}\left(1+e h p \frac{\left(P_{t o t}-P_{e n g}\right)}{P_{\max }}\right)
$$

$\xi_{b}=$ Base fuel to power efficiency (depends on the technology type: gasoline vs. diesel)

$P_{\max }=$ Rated engine power $(\mathrm{kW})$

ehp =Proportionate decrease in efficiency at high output power (dimensionless)

$P_{\text {tot }} \quad=$ Total power $(\mathrm{kW})$

$d F u e l=$ Excess fuel conception due to congestion as a percentage
Tires are another main aspect of vehicle operating cost. Tire wear can vary depending on the driving pattern, temperature, and the surface. Chatti and Zaabar [3] found out that for every $1 \mathrm{~m} / \mathrm{km}$ increase in roughness, tire wear is escalated by $1 \%$ for heavy trucks at $88 \mathrm{~km} / \mathrm{h}$. Sandberg [5] found out that when IRI is increased from $1-10 \mathrm{~m} / \mathrm{km}$, the rolling resistance increased by $19 \%$ at $54 \mathrm{~km} / \mathrm{h}$. The same was $48 \%$ at $90 \mathrm{~km} / \mathrm{h}$. Therefore it is clear that pavement roughness is proportional to tire consumption as well. HDM-4 uses the following model to calculate tire consumption [3].

$$
\mathrm{TC}=\frac{\mathrm{NW} * \mathrm{EQNT}}{\mathrm{MODFAC}}
$$

Where:

$T C=$ Tire consumption per vehicle $(\% \mathrm{~km})$

$N W=$ Number of wheels

$E Q N T=$ Equivalent new tire $(\% \mathrm{~km})$

$M O D F A C=$ Tire life modification factor

\section{4) Parts consumption}

Chatti and Zaabar [3] found out that roughness of up to $3 \mathrm{~m} / \mathrm{km}$ had no impact on maintenance cost, but beyond that the cos twill increase. IRI decrease by $1 \mathrm{~m} / \mathrm{km}$ resulted in savings of 24 to 73 billion dollars per year in US context in repair and maintenance cost alone, as per their findings. IRI change of $3 \mathrm{~m} / \mathrm{km}$ to $4 \mathrm{~m} / \mathrm{km}$ resulted $10 \%$ increase of operating cost in their study. The following model is used in HDM-4 for the calculation of parts consumption.

$$
\begin{gathered}
\mathrm{PARTS}=\left(\mathrm{K} 0_{\mathrm{pc}}\left[\mathrm{CKM}^{\mathrm{kp}}\left(\mathrm{a}_{0}+\mathrm{a}_{1} \mathrm{RI}\right)\right]+\mathrm{K} 1_{\mathrm{pc}}\right)(1+\mathrm{CPCON} \\
\times \mathrm{dFUEL}) \\
a_{2}=I R I 0-a_{5} \\
a_{3}=\frac{a_{5}}{I R I 0^{\frac{I R I 0}{a_{5}}}} \\
a_{4}=\frac{I R I 0}{a_{4}} \\
a_{5}=I R I 0-3 \\
\mathrm{LH}=\mathrm{K}_{1 \mathrm{~h}}\left(a_{6} \times \mathrm{PARTS}^{\mathrm{a} 7}\right)+\mathrm{K} 1_{\mathrm{lh}}
\end{gathered}
$$

Where:

PARTS $=$ Standardized parts consumption as a fraction of the replacement vehicle price per $1000 \mathrm{~km}$ 
$\mathrm{K} 0_{\mathrm{pc}}=$ Rotational calibration factor $($ default $=1.0)$

$\mathrm{CKM}=$ Vehicle Cumulative Kilometer

$\mathrm{a}_{0},{ }^{\mathrm{a}} 1, \mathrm{kp}=$ Model constants

$\mathrm{RI}=$ Adjusted roughness

IRI = Roughness in IRI $(\mathrm{m} / \mathrm{km})$

IRI0 = Limiting roughness for parts consumption in IRI $(3 \mathrm{~m} / \mathrm{km})$

$a_{2}$ to $a_{5}=$ Model parameters

$\mathrm{K} 1_{\mathrm{pc}}=$ Translational calibration factor $($ default $=0.0)$

CPCON=Congestion elasticity factor $($ default $=0.1)$

dFUEL=Additional fuel consumption due to congestion as a decimal

$\mathrm{LH}=$ Number of labor hours per 1000km

$\mathrm{K}_{\mathrm{lh}}=$ Rotation calibration factor $($ default=1)

$\mathrm{K}_{1 \mathrm{~h}}=$ Translation calibration factor $($ default $=0)$

$a_{6}, a_{7}=$ Model constants

$\mathrm{RI}$ and a3 would eliminate the effect of roughness at low IRI values.

\section{B. Effect of Roughness on Travel Time}

Earlier, it was believed that roughness had no impact on the operating speed of the vehicle. But it is natural for drivers to drive faster on a smooth road as it is both comfortable and safe to do so. T. Wang et al. [6] found out that vehicles achieve the best fuel economy around 60 to $80 \mathrm{~km} / \mathrm{h}$. It is important that drivers can achieve those speeds to keep travel time at par and it affects the operating cost as well due to low fuel consumption. He has used the following regression model to demonstrate the impact of roughness on travel speed.

$$
\begin{gathered}
y=30.7368+1.0375 R C I-11.2421 x_{2}+0.0062 x_{3}{ }^{2} \\
R C I=7.254-9.984 \log I R I
\end{gathered}
$$

Where, $\mathrm{y}$ is the average highway speed in kilometers per hour $(\mathrm{km} / \mathrm{h}) ; \mathrm{x}_{2}$ is the ratio of traffic volume to the total capacity of roadway; and $\mathrm{x}_{3}$ is the speed limit, in $\mathrm{km} / \mathrm{h}$.

\section{Delays in A Work Zone}

Highway Work zones will result in narrowed roadways, closed down lanes, below standard temporary lanes etc. which will invariably cause delays to the road users [7].

Delay time is an aggregation of the following components:
- Speed change delay is the additional time necessary to decelerate from the upstream approach speed to the work zone speed and then to accelerate back to the initial approach speed after traversing the work zone under unrestricted (free) traffic flow.

- Reduced speed delay is the additional time necessary to traverse the work zone at the lower posted speed; it depends on the upstream and work zone speed differential and length of the work zone under both unrestricted and restricted (forced) traffic flow.

- Detour delay is the additional time necessary to travel the excess distance by selecting a detour route.

- Stopping delay is the additional time necessary to come to a complete stop from the upstream approach speed (instead of just slowing to the work zone speed) and the additional time to accelerate back to the approach speed after traversing the work zone under restricted traffic flow.

- Queue delay is the additional time necessary to creep through the queue under restricted traffic flow.

\section{Case Study for 4 Lane Urban Arterial RoAd in SRI LANKA}

The case study is done on a major arterial road in Sri Lanka, connecting two major cities, Kandy and Colombo. The road is originally a 2 lane highway being rehabilitated and widened in to a4 lane highway from Belummahara to Nittambuwa. The section length is $29 \mathrm{~km}$ and the project cost is 4 .billion $\mathrm{LKR}^{1}$ The project duration is 2years.

This study has adopted an analytical approach using HDM4 developed by World Bank [3] to estimate the vehicle operating costs and delay costs. HDM-4 model is widely used to estimate vehicle operating cost for highway project evaluations and the model results have been validated by many studies done in several countries.

The software was calibrated using data obtained from a study conducted by study conducted for HDM-4 calibration for Sri Lanka by Pasindu and Mampearachchi[8]. Further, the monetary values for Value of Time of a person (VOT) are obtained from the report "Assessing Public Investment in the Transport Sector," Ministry of Finance, Sri Lanka, 2000[9].

Speed surveys were carried out on the road segment near the work zone and under normal operating conditions. There is a significant reduction in speeds of all vehicle types, especially the heavy vehicles such as buses, trucks. This leads to the delays and economic loss due travel time increase.

Following table shows the scenarios simulated in the study

TABLE I

\begin{tabular}{llll}
\multicolumn{4}{c}{ SimULATED SCENARIOS } \\
\hline Scenario & Peak & Off peak & Night time \\
\hline Duration & 6 hours/day & 8 hours/day & 10 hours/day \\
Traffic percentage & $50 \%$ & $30 \%$ & $20 \%$ \\
\hline
\end{tabular}

${ }^{1}$ Calculated at $150 \mathrm{LKR}=1 \mathrm{USD}$ exchange rate 


\begin{tabular}{llll}
\hline Speed WZ/Normal $(\mathrm{km} / \mathrm{h})$ & $20 / 30$ & $30 / 40$ & $40 / 50$ \\
\hline
\end{tabular}

Following table shows the composition of vehicles on the selected road section.

TABLE II

VEHICLE COMPOSITION IN A1

\begin{tabular}{lllllll}
\hline & $\begin{array}{l}\text { Three } \\
\text { wheel }\end{array}$ & Car & Bus & Truck & $\begin{array}{l}\text { Motor } \\
\text { cycle }\end{array}$ & AADT \\
\hline $\begin{array}{l}\text { Percentag } \\
\text { e }\end{array}$ & $\begin{array}{l}16.00 \\
\%\end{array}$ & $36.00 \%$ & $11.00 \%$ & $18.00 \%$ & $19.00 \%$ & $100.00 \%$ \\
$\begin{array}{l}\text { Traffic } \\
\text { count }\end{array}$ & 6796 & 15291 & 4672 & 7646 & 8070 & 42475 \\
\hline
\end{tabular}

Following tables demonstrate the travel speed variation during the day in work zone and normal road section along the A1 corridor.

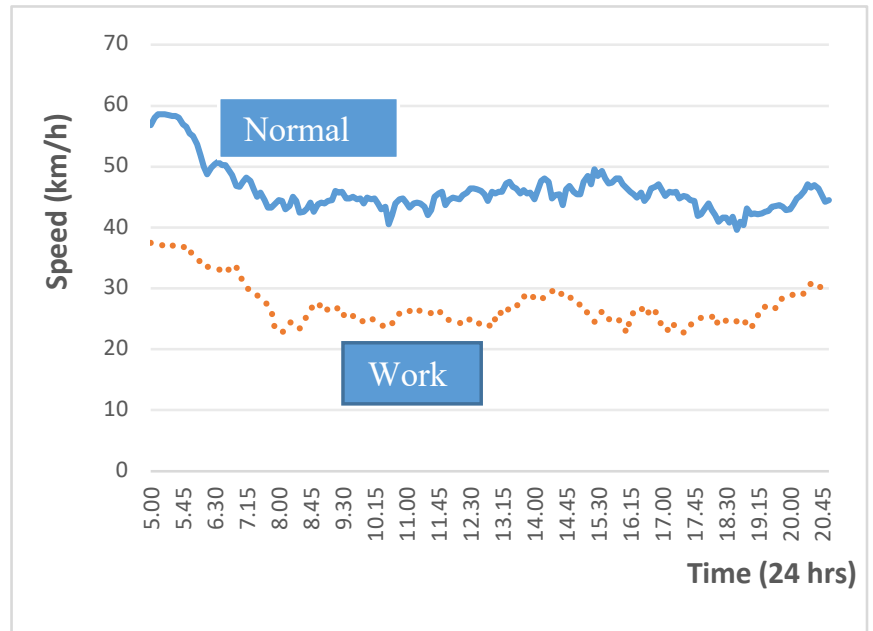

Fig.1 Comparison of travel time

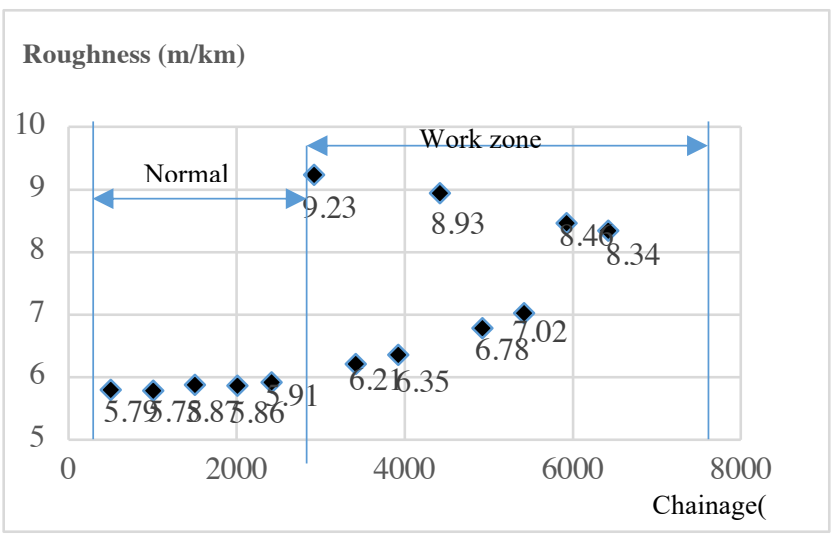

Fig.2 Roughness variation along the considered section

Following figure shows the roughness figures obtained along the A1 corridor during data collection. miniROMDAS [10] bump integrator mounted on a 1986 Land Rover Defender was used in the data collection. Data collection method was Quarter car method. Calibration was done using ROMDAS Z250[11].

\section{ANALYSIS}

Variation of VOC against roughness and average speed of the vehicles is compared. Here, normal section is assumed to be having $40 \mathrm{~km} / \mathrm{h}$ operating speed and $5 \mathrm{~m} / \mathrm{km}$ roughness while the work zone would operate at $20 \mathrm{~km} / \mathrm{h}$ and $9 \mathrm{~m} / \mathrm{km}$ roughness. The assumptions are based on the collected data from the A1 corridor. Abbreviation of LKR is used for Sri Lankan Rupees.

TABLE III

VOC VALUES FOR $20 \mathrm{KM} / \mathrm{H}$

\begin{tabular}{llllll}
\hline Roughness & \multicolumn{4}{l}{ Total Cost per 1000 veh-km (LKR) } \\
& Threewheel & Car & $\begin{array}{l}\text { Heavy } \\
\text { Bus }\end{array}$ & $\begin{array}{l}\text { Medium } \\
\text { Truck }\end{array}$ & $\begin{array}{l}\text { Motor } \\
\text { Cycle }\end{array}$ \\
\hline 5 & 10317 & 36472 & 58625 & 42683 & 4207 \\
6 & 10499 & 36897 & 59795 & 43501 & 4286 \\
7 & 10744 & 37425 & 61302 & 44518 & 4393 \\
8 & 11052 & 38088 & 63233 & 45797 & 4525 \\
9 & 11420 & 38957 & 65696 & 47439 & 4685 \\
10 & 11879 & 40164 & 68719 & 49622 & 4884 \\
\hline
\end{tabular}

TABLE IV

VOC VALUES FOR $40 \mathrm{KM} / \mathrm{H}$

Roughness $\quad$ Total Cost per 1000 veh-km (LKR)

\begin{tabular}{llllll} 
& Threewheel & Car & $\begin{array}{l}\text { Heavy } \\
\text { Bus }\end{array}$ & $\begin{array}{l}\text { Medium } \\
\text { Truck }\end{array}$ & $\begin{array}{l}\text { Motor } \\
\text { Cycle }\end{array}$ \\
\hline 5 & 8505 & 29332 & 48454 & 37571 & 3786 \\
6 & 8697 & 29799 & 49662 & 38419 & 3867 \\
7 & 8955 & 30379 & 51193 & 39472 & 3976 \\
8 & 9279 & 31107 & 53167 & 40829 & 4111 \\
9 & 9676 & 32078 & 55774 & 42640 & 4275 \\
10 & 10205 & 33568 & 59258 & 45074 & 4485 \\
11 & 10850 & 35766 & 64183 & 48265 & 4714 \\
12 & 11218 & 37182 & 67968 & 50621 & 4832 \\
\hline
\end{tabular}

The above values were used to calculate the total cost per year by multiplying them with the AADT and composition values of Table 1 to obtain vehicle kilometers. Comparison of the total costs per day is given in the table below.

TABLE V

COMPARISON OF VOC BETWEEN THE TWO SECTIONS

\begin{tabular}{llll}
\hline Vehicle type & $\begin{array}{l}\text { VOC (Roughness } \\
8 \mathrm{~m} / \mathrm{km}, 20 \mathrm{~km} / \mathrm{h})\end{array}$ & $\begin{array}{l}\text { VOC (Roughness } \\
5 \mathrm{~m} / \mathrm{km}, 30 \mathrm{~km} / \mathrm{h})\end{array}$ & Difference \\
\hline Three wheel & 11,052 & 9,555 & 1,496 \\
Car & 36,472 & 33,622 & 2,850 \\
\hline
\end{tabular}




\begin{tabular}{llll}
\hline Bus & 58,625 & 54,402 & 4,223 \\
Truck & 42,683 & 40,444 & 2,239 \\
Motor Cycle & 4,207 & 3,992 & 215 \\
Total & & & 11,022 \\
\hline
\end{tabular}

For an AADT of 40,000 veh/day for the stretch of $10 \mathrm{~km}$, which is the length of the considered work zone, the above values add up as follows.

TABLE VI

COST INCREASE DUE TO WORK ZONE

\begin{tabular}{llll}
\hline $\begin{array}{l}\text { Vehicle } \\
\text { type }\end{array}$ & Difference & $\begin{array}{l}\text { Traffic } \\
\text { volume }\end{array}$ & $\begin{array}{l}\text { Increased } \\
\text { cost per 10 } \\
\text { km stretch }\end{array}$ \\
\hline $\begin{array}{l}\text { Three } \\
\text { wheel }\end{array}$ & 1,496 & 6,796 & 101,676 \\
Car & 2,850 & 15,291 & 435,771 \\
Bus & 4,223 & 4,672 & 197,275 \\
Truck & 2,239 & 7,645 & 171,144 \\
$\begin{array}{l}\text { Motor } \\
\text { Cycle }\end{array}$ & 215 & 8,070 & 17,339 \\
Total & & 42,474 & 923,205 \\
\hline
\end{tabular}

Value of time (VOT) valuesadopted for delay cost calculation is given below [12].

TABLE VII

\begin{tabular}{lllll}
\multicolumn{5}{c}{ TABLE VII } \\
Vehicle type & $\begin{array}{l}\text { VOT } \\
\text { (LKR/hr) } \\
\text { Morning/Night }\end{array}$ & $\begin{array}{l}\text { Morning } \\
\text { peak }\end{array}$ & Mid-day & $\begin{array}{l}\text { Evening } \\
\text { Peak }\end{array}$ \\
\hline Three wheel & 104 & 377 & 245 & 321 \\
Car & 180 & 687 & 392 & 621 \\
Bus & 64 & 186 & 81 & 174 \\
Truck & 850 & 850 & 850 & 850 \\
Motor Cycle & 83 & 302 & 227 & 272 \\
\hline
\end{tabular}

The observed delays for vehicles in comparison to the normal road section are as follows.

\begin{tabular}{llll}
\multicolumn{4}{c}{ TABLE VIII } \\
DELAY TIMES & \\
\hline Early morning + & Morning peak & Mid-day & Evening peak \\
Night & & & \\
\hline $0.08 \mathrm{~h}$ & $0.07 \mathrm{~h}$ & $0.12 \mathrm{~h}$ & $0.12 \mathrm{~h}$ \\
\hline
\end{tabular}

As per the above delays, the computed total delay against the observed traffic flow composition adds up to about 1.8 million LKR per day.

TABLE IX

DELAy Cost For EACH VeHICLE TYPE Vehicle type VOT (LKR/day)

\begin{tabular}{ll}
\hline Three wheel & 189,717 \\
Car & 752,684 \\
Bus & 58,309 \\
Truck & 610,875 \\
Motor Cycle & 206,437 \\
TOTAL & $1,818,023$ \\
\hline
\end{tabular}

Travel time delay cost + VOC $=$ Economic cost

$1,818,000+923,205=2,741,205 /=$ LKR per day.

Economic cost per year with 300 days of similar traffic is about 700 million LKR (Equivalent of 4.6 million USD).

\section{CONCLUSION}

From the simulation results, it can be observed that vehicle operating cost is sensitive to roughness and speed. The roughness of the temporary lane has a significant effect on the economic cost, so maintaining it at a set level will save on cost to the road users. The biggest saving can be achieved by proper traffic planning, in order to reduce delays to road users. Results of this study can be used to calculate the economic impact during the construction phase, and provide strategies to minimize it. For an example, the study revealed that at a roughness of 5 or $6 \mathrm{~m} / \mathrm{km}$, it would result in mean speeds closer to that of a normal road section. Hence, the VOC and delay would be reduced which will result in economic savings. Further, the analysis method can be used to evaluate the impact of low volume roads as well.

Limitations of this study include using average speed for the sections. Study can be further improved by using driving cycle models. Also, the speed drop of each individual vehicle type from normal section to work zone is not considered. Further, even though economic cost normally includes VOC, VOT, Accident cost, Emission cost, and so many other factors, only the comparison for VOC and VOT was done due to limitation in data collection.

\section{ACKNOWLEDGEMENT}

This research was funded by Department of Motor traffic - Vehicular Emission Test Trust Fund, Sri Lanka.

\section{REFERENCES}

[1] Andrew. S. Griffith and McGregor Lynde., "Assessing Public Inconvenience in Highway Work Zones," Final Report, SPR Project, Oregon Department of Transportation and Federal Highway Administration Washington, D.C., 2002.

[2] Mettananda T.M.M.B., and Pasindu H.R., "Study on work zone management in highway rehabilitation projects in urban areas; A project report," Road safety and highway: Transport research forum, Department of Civil engineering, University of Moratuwa, Sri Lanka, 2015

[3] Chatti, E. K. and I. Zaabar, "NCHRP Report 720: Estimating the Effects of Pavement Condition on Vehicle Operating Costs," Transportation Research Board of the National Academies, Washington, D.C., 2012.

[4] Paterson, W and Watanatada, T., "Relationships Between Vehicle Speed, Ride Quality, and Road Roughness. Measuring Road Roughness 
and Its Effects on User Cost and Comfort," Philadelphia : American Society for Testing and Materials, 1985.

[5] Sandberg U. "Rolling resistance - basic information and state-of-the-art on measurement methods," Deliverable in Sub- phase 1 of project MIRIAM, 2011b. Download from http://www.miriamco2.net/Publications/MIRIAM SoA Report Final 110601.pdf.

[6] Wang, T., Harvey, J., Lea J.D., and Kim, C., "Impact of Pavement Roughness on Vehicle Free-Flow Speed, ” 2013.

[7] Road user cost manual: New Jersey Department of Transportation. (2001)

[8] Pasindu, H.R., Mampearachchi W.K., "Internal study for calibration of HDM-4 for Sri Lankan roads," University of Moratuwa, Sri Lanka, 2013.

[9] Kumarage A.S., "Assessing Public Investment in the Transport Sector," Ministry of Finance, Sri Lanka, 2000.

[10] miniROMDAS system, https://romdas.com/miniromdas.html

[11] Z 250 Reference profiler, https://romdas.com/romdas-z250.html

[12] Hamsath, M.H.M. ,Pasindu ,H.R., "Evaluating Road user Cost for Highway Work Zones - Case Study for Urban Upgrading Projects in Sri Lanka," $111^{\text {th }}$ Annual IESL sessions, 2017. 